\title{
5-Nitropyrimidines from 3,3-Diamino(2-nitro)thioacrylamides. Structure of 6-(2-Furfurylamino)-2-(2-furyl)-4-methyithio-5-nitropyrimidine
}

Linden, Anthony ; Heimgartner, Heinz ; Garcia Trimino, Maria Isabel ; Macias Cabrera, Arturo

\begin{abstract}
The single-crystal X-ray structure determination of the product obtained from the methylation of 3,3-bis(2-furfurylamino)-N-(2-furoyl)(2-nitro)thioacrylamide, C14H12N4O4S, shows that the 4methylthio-substituted 5-nitropyrimidine derivative was obtained, not the l-methyl-4-thioxo-substituted derivative as previously reported.
\end{abstract}

DOI: https://doi.org/10.1107/S0108270193008558

Posted at the Zurich Open Repository and Archive, University of Zurich ZORA URL: https://doi.org/10.5167/uzh-86646

Journal Article

Published Version

Originally published at:

Linden, Anthony; Heimgartner, Heinz; Garcia Trimino, Maria Isabel; Macias Cabrera, Arturo (1994). 5-Nitropyrimidines from 3,3-Diamino(2-nitro)thioacrylamides. Structure of 6-(2-Furfurylamino)-2-(2furyl)-4-methyithio-5-nitropyrimidine. Acta Crystallographica. Section C: Crystal Structure Communications, 50:421-424.

DOI: https://doi.org/10.1107/S0108270193008558 
Tableau 1. Coordonnées atomiques et facteurs d'agitation thermique isotrope équivalents $\left(\AA^{2}\right)$

$$
B_{\mathrm{eq}}=\left(8 \pi^{2} / 3\right) \sum_{i} \sum_{j} U_{i j} a_{i}^{*} a_{j}^{*} \mathbf{a}_{i} \cdot \mathbf{a}_{j} .
$$

$\begin{array}{lcrrr} & x & y & z & B_{\text {eq }} \\ \text { C1 } & 0,6779(3) & -0,0679(4) & 0,2321(3) & 4,5(1) \\ \text { C2 } & 0,6905(4) & -0,1935(5) & 0,2777(3) & 5,4(1) \\ \text { C3 } & 0,6030(4) & -0,2848(4) & 0,3517(3) & 5,0(1) \\ \text { C4 } & 0,4999(3) & -0,2550(4) & 0,3805(3) & 4,6(1) \\ \text { C5 } & 0,4888(3) & -0,1292(4) & 0,3332(3) & 4,3(1) \\ \text { C6 } & 0,5766(3) & -0,0332(4) & 0,2595(2) & 3,8(1) \\ \text { C7 } & 0,5674(3) & 0,0985(4) & 0,2074(3) & 4,2(1) \\ \text { C8 } & 0,6609(3) & 0,1971(4) & 0,1439(2) & 3,9(1) \\ \text { C9 } & 0,7778(4) & 0,1693(5) & 0,1254(3) & 5,5(1) \\ \text { O10 } & 0,7592(3) & 0,0109(4) & 0,1533(2) & 6,9(1) \\ \text { C11 } & 0,4017(4) & -0,3612(5) & 0,4577(3) & 6,4(1) \\ \text { C12 } & 0,6557(3) & 0,3311(4) & 0,0935(3) & 4,3(1) \\ \text { C13 } & 0,7426(3) & 0,4355(4) & 0,0267(3) & 4,5(1) \\ \text { C14 } & 0,7311(3) & 0,5666(4) & -0,0192(3) & 4,4(1) \\ \text { C15 } & 0,8160(3) & 0,6710(4) & -0,0864(3) & 4,7(1) \\ \text { C16 } & 0,8036(3) & 0,8023(4) & -0,1328(3) & 4,5(1) \\ \text { C17 } & 0,8854(3) & 0,9056(4) & -0,2003(3) & 4,6(1) \\ \text { C18 } & 0,8648(3) & 1,0335(4) & -0,2459(3) & 4,4(1) \\ \text { O19 } & 0,9461(2) & 1,1049(3) & -0,3235(2) & 4,7(1) \\ \text { C20 } & 0,9299(4) & 1,2268(4) & -0,3811(3) & 5,2(1) \\ \text { C21 } & 1,0436(4) & 1,3029(5) & -0,4520(3) & 6,1(1) \\ \text { O22 } & 0,7871(3) & 1,0781(4) & -0,2173(3) & 7,4(1)\end{array}$

Tableau 2. Paramètres géométriques $\left(\AA \mathrm{A}^{\circ}\right)$

\begin{tabular}{|c|c|c|c|}
\hline $\mathrm{C} 1-\mathrm{C} 2$ & $1,380(7)$ & $\mathrm{C} 9-\mathrm{O} 10$ & $1,404(6)$ \\
\hline $\mathrm{C} 1-\mathrm{C} 6$ & $1,402(6)$ & $\mathrm{C} 12-\mathrm{C} 13$ & $1,348(6)$ \\
\hline $\mathrm{Cl}-\mathrm{OlO}$ & $1,359(6)$ & $\mathrm{C} 13-\mathrm{C} 14$ & $1,422(6)$ \\
\hline $\mathrm{C} 2-\mathrm{C} 3$ & $1,378(7)$ & $\mathrm{C} 14-\mathrm{C} 15$ & $1,343(6)$ \\
\hline $\mathrm{C} 3-\mathrm{C} 4$ & $1,399(6)$ & $\mathrm{C} 15-\mathrm{C} 16$ & $1,431(6)$ \\
\hline C4-C5 & $1,383(6)$ & $\mathrm{C} 16-\mathrm{C} 17$ & $1,328(6)$ \\
\hline $\mathrm{C} 4-\mathrm{C} 11$ & $1,503(7)$ & $\mathrm{C} 17-\mathrm{C} 18$ & $1,448(6)$ \\
\hline $\mathrm{C} 5-\mathrm{C} 6$ & $1,389(6)$ & $\mathrm{C} 18-\mathrm{O} 19$ & $1,333(5)$ \\
\hline $\mathrm{C} 6-\mathrm{C} 7$ & $1,450(6)$ & $\mathrm{C} 18-\mathrm{O} 22$ & $1,209(6)$ \\
\hline $\mathrm{C} 7-\mathrm{C} 8$ & $1,335(6)$ & $\mathrm{O} 19-\mathrm{C} 20$ & $1,442(6)$ \\
\hline $\mathrm{C} 8-\mathrm{C} 9$ & $1,507(6)$ & $\mathrm{C} 20-\mathrm{C} 21$ & $1,497(7)$ \\
\hline $\mathrm{C} 8-\mathrm{C} 12$ & $1,438(6)$ & & \\
\hline $\mathrm{C} 2-\mathrm{C} 1-\mathrm{C} 6$ & $120,8(4)$ & $\mathrm{C} 9-\mathrm{C} 8-\mathrm{C} 12$ & $118,5(4)$ \\
\hline $\mathrm{C} 2-\mathrm{Cl}-\mathrm{O} 10$ & $117,9(4)$ & $\mathrm{C} 8-\mathrm{C} 9-\mathrm{O} 10$ & $116,4(4)$ \\
\hline $\mathrm{C} 6-\mathrm{Cl}-\mathrm{O} 10$ & $121,2(4)$ & $\mathrm{C} 1-\mathrm{O} 10-\mathrm{C} 9$ & $120,8(4)$ \\
\hline $\mathrm{C} 1-\mathrm{C} 2-\mathrm{C} 3$ & 119,5 (4) & $\mathrm{C} 8-\mathrm{C} 12-\mathrm{C} 13$ & $127,4(4)$ \\
\hline $\mathrm{C} 2-\mathrm{C} 3-\mathrm{C} 4$ & $121,5(4)$ & $\mathrm{Cl} 2-\mathrm{Cl} 3-\mathrm{Cl} 4$ & $123,9(4)$ \\
\hline $\mathrm{C} 3-\mathrm{C} 4-\mathrm{C} 5$ & $118,0(4)$ & $\mathrm{C} 13-\mathrm{C} 14-\mathrm{C} 15$ & $124,8(4)$ \\
\hline $\mathrm{C} 3-\mathrm{C} 4-\mathrm{C} 11$ & $120,6(4)$ & $\mathrm{C} 14-\mathrm{C} 15-\mathrm{C} 16$ & $124,6(4)$ \\
\hline $\mathrm{C} 5-\mathrm{C} 4-\mathrm{C} 11$ & $121,4(4)$ & $\mathrm{C} 15-\mathrm{C} 16-\mathrm{C} 17$ & $125,6(4)$ \\
\hline $\mathrm{C} 4-\mathrm{C} 5-\mathrm{C} 6$ & $122,0(4)$ & $\mathrm{C} 16-\mathrm{C} 17-\mathrm{C} 18$ & $122,5(4)$ \\
\hline $\mathrm{C} 1-\mathrm{C} 6-\mathrm{C} 5$ & $118,3(4)$ & $\mathrm{C} 17-\mathrm{C} 18-\mathrm{O} 19$ & $112,1(4)$ \\
\hline $\mathrm{Cl}-\mathrm{C} 6-\mathrm{C} 7$ & $118,1(4)$ & $\mathrm{C} 17-\mathrm{C} 18-\mathrm{O} 22$ & $126,0(4)$ \\
\hline $\mathrm{C} 5-\mathrm{C} 6-\mathrm{C} 7$ & $123,6(4)$ & $\mathrm{O} 19-\mathrm{C} 18-\mathrm{O} 22$ & $121,8(4)$ \\
\hline $\mathrm{C} 6-\mathrm{C} 7-\mathrm{C} 8$ & $121,5(4)$ & $\mathrm{C} 18-\mathrm{O} 19-\mathrm{C} 20$ & $117,8(3)$ \\
\hline $\mathrm{C} 7-\mathrm{C} 8-\mathrm{C} 9$ & 119,0 (4) & $\mathrm{O} 19-\mathrm{C} 20-\mathrm{C} 21$ & $107,1(4)$ \\
\hline $\mathrm{C} 7-\mathrm{C} 8-\mathrm{C} 12$ & $122,5(4)$ & & \\
\hline
\end{tabular}

Collection des données: CAD-4 Software (Enraf-Nonius, 1989). Affinement des paramètres de la maille: $C A D-4$ Software. Programme(s) pour la solution de la structure: MULTAN80 (Main, Fiske, Hull, Lessinger, Germain, Declercq \& Woolfson, 1980).

Les listes des facteurs de structure, des facteurs d'agitation thermique anisotrope, des coordonnées des atomes d'hydrogène et des distances et angles des atomes d'hydrogène ont été déposées au dépôt d'archives de la British Library Document Supply Centre (Supplementary Publication No. SUP 71681: $21 \mathrm{pp}$.). On peut en obtenir des copies en s'adressant à: The Technical Editor, International Union of Crystallography, 5 Abbey Square, Chester CH1 2HU, Angleterre. [Référence de CIF: PA 1072]

s. 1994 International Union of Crystallography Printed in Cireat Britain - all rights reserved

\section{Références}

Enraf-Nonius (1989). CAD-4 Software. Version 5.0. Enraf-Nonius, Delft, Les Pays-Bas.

Loeliger, P., Bollag, W. \& Maier, H. (1980). Eur. J. Med. 15, 9-15.

Main, P., Fiske, S. J., Hull, S. E., Lessinger, L., Germain, G., Declercq, J.-P. \& Woolfson, M. M. (1980). MULTAN80. A System of Computer Programs for the Automatic Solution of Crystal Structures from X-ray Diffraction Data. Univ. de York, Angleterre, et de Louvain, Belgique.

Schomaker, V., Waser, J., Marsh, R. E. \& Bergman, G. (1959). Acta Cryst. 12, 600-604.

Stewart, R. F., Davidson, E. R. \& Simpson, W. T. (1965). J. Chem. Phys. 42, 3175-3187.

Acta Cryst. (1994). C50, 421-424

\section{5-Nitropyrimidines from 3,3-Diamino(2- nitro)thioacrylamides. Structure of 6-(2-Furfurylamino)-2-(2-furyl)-4- methylthio-5-nitropyrimidine}

\author{
Anthony Linden and Heinz Heimgartner \\ Organisch-chemisches Institut, Universität Zürich, \\ Maria Isabel García Trimiño and \\ Arturo Macías Cabrera \\ National Center for Scientific Research, \\ Laboratory of Organic Synthesis, \\ PO Box 6990, Havanna, Cuba
} Winterthurerstrasse 190, CH-8057 Zürich, Switzerland

(Received 29 June 1993; accepted 10 August 1993)

\begin{abstract}
The single-crystal X-ray structure determination of the product obtained from the methylation of 3,3-bis(2furfurylamino)- $\mathrm{N}$-(2-furoyl)(2-nitro)thioacrylamide, $\mathrm{C}_{14}$ $\mathrm{H}_{12} \mathrm{~N}_{4} \mathrm{O}_{4} \mathrm{~S}$, shows that the 4-methylthio-substituted 5nitropyrimidine derivative was obtained, not the 1methyl-4-thioxo-substituted derivative as previously reported.
\end{abstract}

\section{Comment}

The biological importance of nitro-heterocycles is well known. Specifically, some 5-nitropyrimidine derivatives have been reported to show antimitotic activity (Jamoulle et al., 1980) or to be useful as fungicides (Lobov, Stopkan, Cherepenko \& Cherkasov, 1965). 5-Nitropyrimidin-2-amine (Enheptin-P) has been used as an effective drug in the therapy of a common protozoan infection in turkeys, known as enterohepatitis (Waletzky, Clark 
\& Marson, 1950). 2,4-Diamino-6-(p-bromoanilino)-5nitropyrimidine is active against the Walker 256 tumour in rats (O'Brien, Cheng \& Pfleiderer, 1966), 5nitropyrimidine-4,6-diol inhibits the growth of the SSK sarcoma in rats (Grekh, 1965) and 2,4-diamino-6-methyl5-nitropyrimidine retards the growth of the Crocker sarcoma in mice at $50 \mathrm{mg} \mathrm{kg}^{-1}$ (Aksamitnaya, 1963).

Recently, we described the synthesis of new 5nitropyrimidine derivatives, starting from $N$-acyl-3,3diamino(2-nitro)thioacrylamides and proceeding via $S$-methyl $\mathrm{N}$-acyl-3,3-diamino(2-nitro)thioacrylimidate hydroiodides (Garcia Trimiño, Macías Cabrera \& Vélez Castro, 1992). Based on the available spectroscopic data (IR, ${ }^{1} \mathrm{H}$ NMR and MS) and consideration of the likely mechanism of the reaction, it was proposed that the thioimidate salts cyclize upon heating to 6-amino-4methylthio-5-nitropyrimidinium iodides (I), which finally transform to the 6-amino-5-nitro-4-thioxopyrimidines.

Subsequently, studies by ${ }^{13} \mathrm{C}$ NMR and the X-ray structure determinations of two of the derivatives have shown that the 6-amino-4-methylthio-5-nitropyrimidines (II) were the actual products. The X-ray structure of 6methylamino-4-methylthio-5-nitro-2-phenylpyrimidine [(II $\left.a), R=\mathrm{H}, R^{\prime}=\mathrm{Ph}\right]$ has been determined by Pomes,<smiles>[R]CNc1c([N+](=O)[O-])c(Cl)nc([R])[n+]1CC</smiles>

(I)

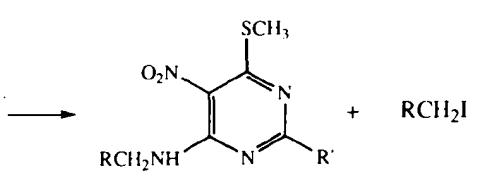

(II)
Duque, Novoa \& Garcia Trimiño (1994). In the present work, the structure of 6-(2-furfurylamino)-2-(2-furyl)-4methylthio-5-nitropyrimidine [(II $b), R=2$-furyl, $R^{\prime}=2$ furyl] is reported.

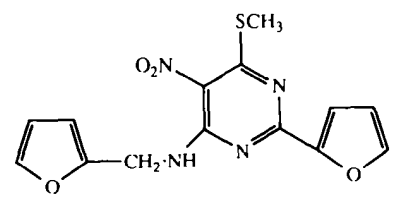

(IIb)

These later findings suggest that in (I) the nucleophilic attack by the iodide anion occurs at the $\mathrm{C}$ atom attached to $\mathrm{N}(1)$ of the pyrimidine ring, instead of, as originally proposed, at the $\mathrm{C}$ atom of the $-\mathrm{SCH}_{3}$ group. Such an attack can be explained by the increased electrophilicity of the $\mathrm{C}$ atom attached to the positively charged $\mathrm{N}(1)$ atom of the pyrimidinium salt. Similar behaviour has been described previously in the case of 1-substituted 4methylthio-pyridinium salts (Spitzner, Lesinski, Richter \& Schroth, 1987).
A view of a molecule of (Il $b$ ) is shown in Fig. 1. The structure does not exhibit any unusual features. There is an intramolecular hydrogen bond between the amine $\mathrm{H}$ atom and the nearest $\mathrm{O}$ atom of the nitro group. The contact distance $\mathrm{H}(6) \cdots \mathrm{O}(2)$ is $1.89(3) \AA$. The pyrimidine ring and the 2-(2-furyl) substituent are coplanar, which indicates an extension of the delocalized $\pi$-bonding system across both rings. A least-squares-planes calculation involving the atoms of both rings plus the atoms $S, N(5)$ and $N(6)$ showed that the maximum deviation from planarity was $0.05 \AA$ at $\mathrm{N}(5)$.

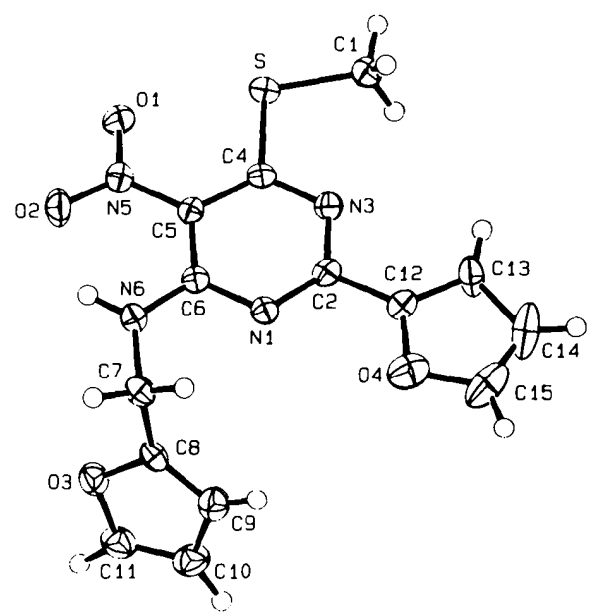

Fig. 1. View of a molecule of (II $b$ ) showing the atom-labelling scheme. Thermal ellipsoids are drawn at the $50 \%$ probability level. $\mathrm{H}$ atoms are represented by spheres of arbitrary size.

\section{Experimental}

6-(2-Furfurylamino)-2-(2-furyl)-4-methylthio-5-nitropyrimidine was obtained in $65 \%$ yield by methylation of $3,3-$ bis(2-furfurylamino)- $N$-(2-furoyl)(2-nitro)thioacrylamide with $\mathrm{CH}_{3} \mathrm{I}$ in ethanol (Garcia Trimiño, Macías Cabrera \& Vélez Castro, 1992). Recrystallization from acetone gave light yellow needles (m.p. 432-434 K).

$$
\begin{aligned}
& \text { Crystal data } \\
& \mathrm{C}_{14} \mathrm{H}_{12} \mathrm{~N}_{4} \mathrm{O}_{4} \mathrm{~S} \\
& M_{r}=332.33 \\
& \text { Triclinic } \\
& P \overline{1} \\
& a=11.099(3) \AA \\
& b=15.200(4) \AA \\
& c=4.416(2) \AA \\
& \alpha=95.23(3)^{\circ} \\
& \beta=96.84(3)^{\circ} \\
& \gamma=93.74(2)^{\circ} \\
& V=734.5(4) \AA^{3} \\
& Z=2
\end{aligned}
$$$$
\begin{aligned}
& D_{x}=1.503 \mathrm{Mg} \mathrm{m}^{-3} \\
& \text { Mo } K \alpha \text { radiátion } \\
& \lambda=0.71069 \AA \\
& \text { Cell parameters from } 24 \\
& \quad \text { reflections } \\
& \theta=15-20^{\circ} \\
& \mu=0.235 \mathrm{~mm}^{-1} \\
& T=173(1) \mathrm{K} \\
& \text { Needle } \\
& 0.43 \times 0.10 \times 0.05 \mathrm{~mm} \\
& \text { Yellow }
\end{aligned}
$$

Data collection

Rigaku AFC-5 $R$ diffractome- $\quad R_{\mathrm{int}}=0.033$ 


\section{$\omega / 2 \theta$ scans}

Absorption correction: Walker \& Stuart, 1983)

$T_{\min }=0.86, T_{\max }=1.19$

3546 measured reflections 3374 independent reflections 2134 observed reflections

$$
[I>3 \sigma(I)]
$$

\section{Refinement}

Refinement on $F$

$R=0.0456$

$w R=0.0427$

$S=1.640$

2134 reflections

254 parameters

$\mathrm{H}$ atoms refined isotropically $w=1 /\left[\sigma^{2}\left(F_{o}\right)+\left(0.005 F_{o}\right)^{2}\right]$ $(\Delta / \sigma)_{\max }=0.0005$ empirical (DIFABS:

$$
\begin{aligned}
& h=0 \rightarrow 14 \\
& k=-19 \rightarrow 19 \\
& l=-5 \rightarrow 5 \\
& 3 \text { standard reflections } \\
& \text { monitored every } 150 \\
& \quad \text { reflections } \\
& \text { intensity variation: } \\
& \quad \text { insignificant }
\end{aligned}
$$

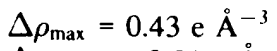
$\Delta \rho_{\min }=-0.31{\mathrm{e} \AA^{-3}}^{-3}$ Extinction correction: Zachariasen (1963) Extinction coefficient: $2(2) \times 10^{-7}$

Atomic scattering factors from International Tables for X-ray Crystallography (1974, Vol. 4)

Table 1. Fractional atomic coordinates and equivalent isotropic displacement parameters $\left(\AA^{2}\right)$

\begin{tabular}{lcccc}
\multicolumn{5}{c}{$U_{\mathrm{eq}}=(1 / 3) \sum_{i} \sum_{j} U_{i j} a_{i}^{*} a_{j}^{*} \mathbf{a}_{i} . \mathbf{a}_{j}}$. \\
$\mathrm{S}$ & $x$ & $y$ & $z$ & $U_{\mathrm{eq}}$ \\
$\mathrm{O}(1)$ & $0.92094(7)$ & $0.92811(5)$ & $1.2329(2)$ & $0.0256(2)$ \\
$\mathrm{O}(2)$ & $1.0883(2)$ & $0.8169(2)$ & $1.2209(5)$ & $0.0358(8)$ \\
$\mathrm{O}(3)$ & $1.1074(2)$ & $0.7036(2)$ & $0.8978(5)$ & $0.0397(8)$ \\
$\mathrm{O}(4)$ & $0.8290(2)$ & $0.4531(1)$ & $0.5065(5)$ & $0.0326(8)$ \\
$\mathrm{N}(1)$ & $0.5294(2)$ & $0.7487(2)$ & $0.1884(6)$ & $0.0477(9)$ \\
$\mathrm{N}(3)$ & $0.7618(2)$ & $0.7246(2)$ & $0.4556(5)$ & $0.0235(8)$ \\
$\mathrm{N}(5)$ & $0.7527(2)$ & $0.8566(2)$ & $0.7966(6)$ & $0.0250(8)$ \\
$\mathrm{N}(6)$ & $1.0478(2)$ & $0.7652(2)$ & $0.9927(6)$ & $0.0273(9)$ \\
$\mathrm{C}(1)$ & $0.9292(2)$ & $0.6447(2)$ & $0.4713(6)$ & $0.0264(9)$ \\
$\mathrm{C}(2)$ & $0.8026(3)$ & $1.0032(2)$ & $1.2092(9)$ & $0.034(1)$ \\
$\mathrm{C}(4)$ & $0.7075(3)$ & $0.7945(2)$ & $0.5652(7)$ & $0.0233(9)$ \\
$\mathrm{C}(5)$ & $0.8630(3)$ & $0.8470(2)$ & $0.9349(6)$ & $0.0214(9)$ \\
$\mathrm{C}(6)$ & $0.9302(3)$ & $0.7749(2)$ & $0.8418(7)$ & $0.0212(9)$ \\
$\mathrm{C}(7)$ & $0.8752(3)$ & $0.7144(2)$ & $0.5895(7)$ & $0.0234(9)$ \\
$\mathrm{C}(8)$ & $0.8665(3)$ & $0.5803(2)$ & $0.2254(7)$ & $0.027(1)$ \\
$\mathrm{C}(9)$ & $0.7797(3)$ & $0.5153(2)$ & $0.3310(7)$ & $0.0249(9)$ \\
$\mathrm{C}(10)$ & $0.6585(3)$ & $0.5006(2)$ & $0.2880(8)$ & $0.037(1)$ \\
$\mathrm{C}(11)$ & $0.6275(3)$ & $0.4248(2)$ & $0.4381(9)$ & $0.040(1)$ \\
$\mathrm{C}(12)$ & $0.7329(3)$ & $0.3988(2)$ & $0.5669(9)$ & $0.038(1)$ \\
$\mathrm{C}(13)$ & $0.5861(3)$ & $0.8074(2)$ & $0.4235(7)$ & $0.027(1)$ \\
$\mathrm{C}(14)$ & $0.5153(3)$ & $0.8723(2)$ & $0.4972(8)$ & $0.037(1)$ \\
$\mathrm{C}(15)$ & $0.4042(4)$ & $0.8520(4)$ & $0.298(1)$ & $0.061(2)$ \\
& $0.4157(4)$ & $0.7800(3)$ & $0.116(1)$ & $0.056(2)$
\end{tabular}

Table 2. Selected geometric parameters $\left(\AA,^{\circ}\right)$

$\begin{array}{llll}\mathrm{S}-\mathrm{C}(1) & 1.796(4) & \mathrm{N}(6)-\mathrm{C}(6) & 1.346(4) \\ \mathrm{S}-\mathrm{C}(4) & 1.751(3) & \mathrm{N}(6)-\mathrm{C}(7) & 1.469(4) \\ \mathrm{O}(1)-\mathrm{N}(5) & 1.240(3) & \mathrm{C}(2)-\mathrm{C}(12) & 1.450(4) \\ \mathrm{O}(2)-\mathrm{N}(5) & 1.251(3) & \mathrm{C}(4)-\mathrm{C}(5) & 1.422(4) \\ \mathrm{O}(3)-\mathrm{C}(8) & 1.377(3) & \mathrm{C}(5)-\mathrm{C}(6) & 1.428(4) \\ \mathrm{O}(3)-\mathrm{C}(11) & 1.371(4) & \mathrm{C}(7)-\mathrm{C}(8) & 1.479(4) \\ \mathrm{O}(4)-\mathrm{C}(12) & 1.368(4) & \mathrm{C}(8)-\mathrm{C}(9) & 1.337(4) \\ \mathrm{O}(4)-\mathrm{C}(15) & 1.389(5) & \mathrm{C}(9)-\mathrm{C}(10) & 1.424(5) \\ \mathrm{N}(1)-\mathrm{C}(2) & 1.336(4) & \mathrm{C}(10)-\mathrm{C}(11) & 1.339(5) \\ \mathrm{N}(1)-\mathrm{C}(6) & 1.350(4) & \mathrm{C}(12)-\mathrm{C}(13) & 1.341(4) \\ \mathrm{N}(3)-\mathrm{C}(2) & 1.353(4) & \mathrm{C}(13)-\mathrm{C}(14) & 1.426(5) \\ \mathrm{N}(3)-\mathrm{C}(4) & 1.325(4) & \mathrm{C}(14)-\mathrm{C}(15) & 1.319(6) \\ \mathrm{N}(5)-\mathrm{C}(5) & 1.417(4) & & \\ \mathrm{C}(1)-\mathrm{S}-\mathrm{C}(4) & 100.5(2) & \mathrm{C}(4)-\mathrm{C}(5)-\mathrm{C}(6) & 117.4(3) \\ \mathrm{C}(8)-\mathrm{O}(3)-\mathrm{C}(11) & 106.3(3) & \mathrm{N}(1)-\mathrm{C}(6)-\mathrm{N}(6) & 115.7(3) \\ \mathrm{C}(12)-\mathrm{O}(4)-\mathrm{C}(15) & 104.9(3) & \mathrm{N}(1)-\mathrm{C}(6)-\mathrm{C}(5) & 120.3(3)\end{array}$

$\begin{array}{llll}\mathrm{C}(2)-\mathrm{N}(1)-\mathrm{C}(6) & 116.7(3) & \mathrm{N}(6)-\mathrm{C}(6)-\mathrm{C}(5) & 124.0(3) \\ \mathrm{C}(2)-\mathrm{N}(3)-\mathrm{C}(4) & 116.7(3) & \mathrm{N}(6)-\mathrm{C}(7)-\mathrm{C}(8) & 113.9(3) \\ \mathrm{O}(1)-\mathrm{N}(5)-\mathrm{O}(2) & 121.4(3) & \mathrm{O}(3)-\mathrm{C}(8)-\mathrm{C}(7) & 116.6(3) \\ \mathrm{O}(1)-\mathrm{N}(5)-\mathrm{C}(5) & 119.1(3) & \mathrm{O}(3)-\mathrm{C}(8)-\mathrm{C}(9) & 109.3(3) \\ \mathrm{O}(2)-\mathrm{N}(5)-\mathrm{C}(5) & 119.5(3) & \mathrm{C}(7)-\mathrm{C}(8)-\mathrm{C}(9) & 134.0(3) \\ \mathrm{C}(6)-\mathrm{N}(6)-\mathrm{C}(7) & 122.5(3) & \mathrm{C}(8)-\mathrm{C}(9)-\mathrm{C}(10) & 107.8(3) \\ \mathrm{N}(1)-\mathrm{C}(2)-\mathrm{N}(3) & 127.6(3) & \mathrm{C}(9)-\mathrm{C}(10)-\mathrm{C}(11) & 106.0(3) \\ \mathrm{N}(1)-\mathrm{C}(2)-\mathrm{C}(12) & 117.8(3) & \mathrm{O}(3)-\mathrm{C}(11)-\mathrm{C}(10) & 110.6(3) \\ \mathrm{N}(3)-\mathrm{C}(2)-\mathrm{C}(12) & 114.6(3) & \mathrm{O}(4)-\mathrm{C}(12)-\mathrm{C}(2) & 120.5(3) \\ \mathrm{S}-\mathrm{C}(4)-\mathrm{N}(3) & 116.3(2) & \mathrm{O}(4)-\mathrm{C}(12)-\mathrm{C}(13) & 111.8(3) \\ \mathrm{S}-\mathrm{C}(4)-\mathrm{C}(5) & 122.4(2) & \mathrm{C}(2)-\mathrm{C}(12)-\mathrm{C}(13) & 127.7(3) \\ \mathrm{N}(3)-\mathrm{C}(4)-\mathrm{C}(5) & 121.3(3) & \mathrm{C}(12)-\mathrm{C}(13)-\mathrm{C}(14) & 105.0(3) \\ \mathrm{N}(5)-\mathrm{C}(5)-\mathrm{C}(4) & 120.7(3) & \mathrm{C}(13)-\mathrm{C}(14)-\mathrm{C}(15) & 108.2(4) \\ \mathrm{N}(5)-\mathrm{C}(5)-\mathrm{C}(6) & 121.9(3) & \mathrm{O}(4)-\mathrm{C}(15)-\mathrm{C}(14) & 110.1(4)\end{array}$

The $\mathrm{H}$ atoms were located from a difference electron density map and refined isotropically, except $\mathrm{H}(13)$ for which the position was calculated and only $U_{\text {iso }}$ refined. Data collection: MSC/AFC Diffractometer Control Software (Molecular Structure Corporation, 1991). Cell refinement: MSC/AFC Diffractometer Control Software. Data reduction: TEXSAN PROCESS (Molecular Structure Corporation, 1985). Program(s) used to solve structure: SHELXS86 (Sheldrick, 1990). Program(s) used to refine structure: TEXSAN $L S$. Molecular graphics: ORTEPII (Johnson, 1976). Software used to prepare material for publication: TEXSAN FINISH.

MIG is grateful to the Swiss Federal Government for the provision of a National Scholarship for Foreign Students.

Lists of structure factors, anisotropic displacement parameters, $\mathrm{H}$-atom coordinates and complete geometry have been deposited with the British Library Document Supply Centre as Supplementary Publication No. SUP 71560 (26 pp.). Copies may be obtained through The Technical Editor, International Union of Crystallography, 5 Abbey Square, Chester CHI 2HU, England. [CIF reference: SH1074]

\section{References}

Aksamitnaya, I. A. (1963). Vopr. Onkol. 9, 29-35; Chem. Abstr. (1964). 60, $9804 \mathrm{c}$.

Garcia Trimiño, M. I., Macías Cabrera, A. \& Vélez Castro, H. (1992). Synth. Commun. 22, 1319-1331.

Grekh, I. F. (1965). Sovrem Probl. Onkol. pp. 74-80; Chem. Abstr. (1966). 64, 14826e.

Jamoulle, J. C., Lapiere, C. L., Bassler, R., Heinen, E., Selak, Z., de Paermentier, F., Lhoest-Gauthier, M. P., Lepoint, A. \& Renard, A. M. (1980). Ann. Pharm. Fr. 38, 267-270.

Johnson, C. K. (1976). ORTEPII. Report ORNL-5138. Oak Ridge National Laboratory, Tennessee, USA.

Lobov, V. P., Stopkan, V. V., Cherepenko, T. I. \& Cherkasov, V. M. (1965). Prikl. Biokhim. i Mikrobiol. 1, 248-249; Chem. Abstr. (1965). 63, 13737c.

Molecular Structure Corporation (1985). TEXSAN. TEXRAY Structure Analysis Package. MSC, 3200 Research Forest Drive, The Woodlands, TX 77381 , USA.

Molecular Structure Corporation (1991). MSC/AFC Diffractometer Control Software. MSC, 3200 Research Forest Drive, The Woodlands, TX 77381, USA.

O'Brien, D. E., Cheng, C. C. \& Pfleiderer, W. (1966). J. Med. Chem. 9, 573-575.

Pomes, R., Duque, J., Novoa, H. \& Garcia Trimiño, M. I. (1994). Acta Cryst. C50. In the press.

Sheldrick, G. M. (1990). Acta Cryst. A46, 467-473.

Spitzner, R., Lesinski, M., Richter, M. \& Schroth, W. (1987). Monatsh. Chem. 118, 485-502. 
Waletzky, E., Clark, J. H. \& Marson, H. W. (1950). Science, 111, 720721.

Walker, N. \& Stuart, D. (1983). Acta Cryst. A39, 158-166.

Zachariasen, W. H. (1963). Acta Cryst. 16, 1139- 1144.

Acta Cryst. (1994). C50, 424425

\section{Structure of a Cyclopropachromene}

Philip E. Brown, William Clegg* and John E. Steele

Department of Chemistry, University of Newcastle, Newcastle upon Tyne NE1 7RU, England

(Received 5 August 1993; accepted 7 September 1993)

\section{Abstract}

The tricyclic molecule 3a-bromo-3,3-dichloro-2a,3a-dihydro-6-methoxy-2,2-dimethyl-2H,3H-cyclopropa[2,3$c$ chromene, $\mathrm{C}_{13} \mathrm{H}_{13} \mathrm{BrCl}_{2} \mathrm{O}_{2}$, has a pyran ring fused to both a benzene ring and a cyclopropane ring, constraining the degree of puckering so that only two $\mathrm{C}$ atoms lie markedly out of the mean plane of the other atoms. The cyclopropane ring is positioned pseudo-axially relative to the pyran ring.

\section{Comment}

The title compound (I) was prepared in order to compare its ease of Ag-ion-assisted solvolysis with that of the corresponding trichloro compound (which has a $\mathrm{Cl}$ in place of the $\mathrm{Br}$ atom). The comparison of the two reactions served to demonstrate the probable mechanism of solvolysis (Brown \& Islam, 1987; Brown, Clegg, Islam \& Steele, 1990).<smiles>[M]C1(C)Oc2cc(OC)ccc2C2(Cl)C1C2(Cl)Br</smiles>

(I)

Although the chroman and chromene ring systems are constituents of the molecules of many natural products and pharmaceutical substances, whose crystal structures have been reported widely, cyclopropa[c]chromene derivatives have not been documented previously.

The conformation of the pyran ring is constrained by the fused benzene and cyclopropane rings, imposing small ring torsion angles about the $\mathrm{C} 4 \mathrm{a}-\mathrm{C} 8 \mathrm{a}$ and $\mathrm{C} 3-$ $\mathrm{C} 4$ bonds ( -3.3 and $-6.7^{\circ}$, respectively). Thus, with reference to the mean plane of the atoms O1, C8a, C4a and
C4 (r.m.s. $\Delta=0.010 \AA$ ), C3 lies only $0.246 \AA$ out of the plane, compared with $0.602 \AA$ for $C 2$. The cyclopropane ring is positioned pseudo-axially, with the $\mathrm{Br}$ atom and the $\mathrm{H}$ atom attached to $\mathrm{C} 3$ occupying pseudo-equatorial sites on the pyran ring (Fig. 1).

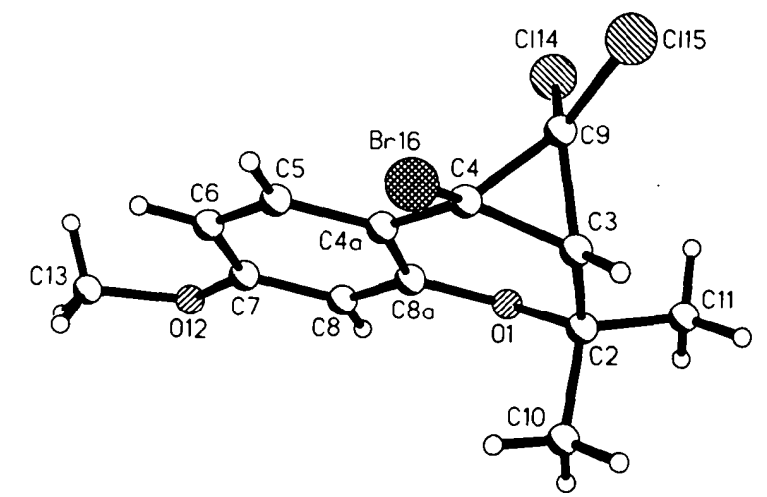

Fig. 1. Molecular structure of the cyclopropachromene illustrating the ring conformations.

The $\mathrm{C}$ atom of the methoxy substituent lies almost in the plane of the benzene ring, allowing some involvement of oxygen in the delocalized $\pi$-bonding system. There are no unusual intramolecular or intermolecular interactions.

\section{Experimental}

The compound was prepared as described previously (Brown, Clegg, Islam \& Steele, 1990) and crystallized from light petroleum.

\section{Crystal data}

$\mathrm{C}_{13} \mathrm{H}_{13} \mathrm{BrCl}_{2} \mathrm{O}_{2}$

$M_{r}=352.04$

Monoclinic

$P 2_{1} / c$

$a=12.434$ (2) $\AA$

$b=10.244(2) \AA$

$c=11.134(2) \AA$

$\beta=100.851(14)^{\circ}$

$V=1392.8(4) \AA^{3}$

$Z=4$

$D_{x}=1.679 \mathrm{Mg} \mathrm{m}^{-3}$

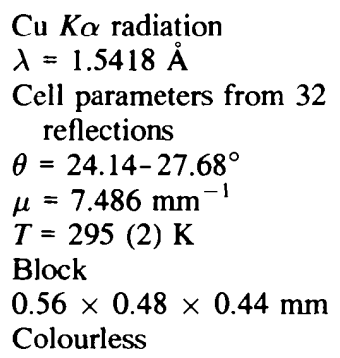

\section{Data collection}

Stoe Siemens diffractometer $\omega / \theta$ scans with on-line pro-

file fitting (Clegg, 1981)

Absorption correction: empirical

$T_{\min }=0.016, T_{\max }=$

0.107

9281 measured reflections

2336 independent reflections

2224 observed reflections

$$
[I>2 \sigma(I)]
$$

$$
\begin{aligned}
& R_{\mathrm{int}}=0.0774 \\
& \theta_{\max }=64.99^{\circ} \\
& h=-14 \rightarrow 14 \\
& k=-12 \rightarrow 12 \\
& l=-12 \rightarrow 12 \\
& 3 \text { standard reflections } \\
& \quad \text { frequency: } 60 \text { min } \\
& \quad \text { intensity variation: } 3 \%
\end{aligned}
$$

